Biol. Neonate 1977;32:I-IV

\title{
Contents, Vol. 32, 1977
}

\section{Contents Vol. 32, 1977}

No. 1-2

Fenton, E.: Technique for in situ Perfusion of the Guinea Pig Placenta 1

Weichsel, M.E., jr.; Clark, B.R., and Poland, R.E.:

Effect of Hypothyroidism on Aspartate Trans-

carbamylase, Uridine Kinase, and DNA Bio

synthesis during Cerebellar Development in

the Rat 5

Vernon, R.G.: Development of Perirenal Adipose

Tissue in the Neonatal Lamb: Effects of

Dietary Safflower Oil 15

Elphick, M.C. and Hull, D.: Incorporation in vivo

of 1-14C-Palmitic Acid into Placental and

Fetal Liver Lipids of the Rabbit 24

Beatty, C.H.; Herrington, P.T., and Bocek, R.M.: Regulation of Cyclic Nucleotide Phosphodiesterase Activity in Rhesus Fetal Muscle .... 33

Matoth, Y. and Zaizov, R.: Factors Affecting Materno-Fetal Transfer of Iron in the Rat . . 43

LeGal, Y.M.; Snellen, J.W., and Littlefield, J.B.: Effects of Large Volume-Hemodilution

Perfusion on Plasma Volume, Plasma Proteins and Plasma Electrolytes in Neonatal Piglets .... 47

Saigal, S. and Usher, R.H.: Symptomatic Neona

tal Plethora 62

Rigo, J. and Senterre, J.: Is Taurine Essential for

the Neonates? 73

Diaz, J.; Schain, R.J., and Bailey, B.G.: Pheno-

barbital-Induced Brain Growth Retardation in

Artificially Reared Rat Pups 77

Milkovic, K.; Peruzovic, M.; Romic, R.; Paunovic,

J., and Pope, K.: Differential Effect of Pre-

and Postnatal Litter Size Reduction on Body

Weight and Development of Stress Response

in the Rat 83

Creter, D.; Goldman, J.A., and Djaldetti, M.: The Fibrinolytic Pathway in the Human Fetus . 94

Lau, H.C.; Horowitz, C,; Jumawan, J., and

Koldovskÿ, O.: Comparison of Postnatal

Development of Several Acid Glycosidases in

the Rat Forebrain and Cerebellum 97 
Pribylová, H.; Melichar, V., and Sabata, V.: The Effect of Prenatal Fructose Infusions upon

Metabolic Condition of the Newborn 108

No. 3-4

Lemaitre, B.; Toubas, P.L.; Guillot, M.; Dreux, C, and Relier, J.P.: Changes of Serum Gonadotropin Concentrations in Premature Babies

Submitted to Phototherapy 113

Stulcová, B.: Postnatal Development of Cardiac

Output Distribution Measured by Radioactive

Microspheres in Rats 119

Gilbert, M. and Jost, A.: Hyperglycemia and

Glycogen Storage in the Rabbit Fetal Liver.

Role of Age and Hormonal Status 125

Michaud, N.J. and Burton, A.F.: Maternal-Fetal Relationships in Corticosteroid Metabolism .

132

Warszawski, D.; Gorodischer, R.; Moses, S.W., and Bark, H.: Caffeine Pharmacokinetics in

Young and Adult Dogs 138

Cresteil, T.: Noradrenaline Appearance in Guinea Pig Brown Adipose Tissue. Its Significance in

Neonatal Nonshivering Thermogenesis .... 143

Yoshioka, T.; Utsumi, K., and Sekiba, K.: Super-oxide Dismutase Activity and Lipid Peroxidation of the Rat Liver during Development . . 147

Robinson, B.H.; Sherwood, W.G., and Oei, J.: The Development of Pyruvate Dehydrogenase in the Subhuman Primate Macaca mulatto . 154

Sato, H.; Katoh-Semba, R., and Kashiwamata, S.:

Effect of Irradiation on the Erythrocyte

Membranes of Homozygous Gunn Rat Suck

lings 158

Gottlieb, A.; Keydar, I., and Epstein, H.T.:

Rodent Brain Growth Stages: An Analytical

Review 166

Cunico, R.L.; Maibach, H.I.; Khan, H., and

Bloom, E.: Skin Barrier Properties_in the

Newborn. Transepidermal Water Loss and

Carbon Dioxide Emission Rates $\quad .177$

Carlsson, R.N.K. and Ingvarsson, B.I.: Decreased Alpha-Fetoprotein Concentration in Neonatal

Pigs after Injection of Adult Swine Serum . . . 183

Naeye, R.L.: Placental Abnormalities in Victims of the Sudden Infant Death Syndrome .... 189

Lawson, D.L.; Miale, T.D.; Harvey, J.L.; Bucciarelli, R.L., and Nelson, L.S.: Leukocyte

Diaphorase Deficiency in Congenital Methe-

IV

Contents

moglobinemia: a Valuable Prognostic Indica

tor 193 
Jensen, M.H. and $\mathrm{J}<$ kgensen, S.: Oxypurine Ex cretion in Normal Newborn Infants 197 Zamenhof, S. and Guthrie, D.: Differential Re sponses to Prenatal Malnutrition among Neo natal Rats 205 Jumawan, J.; Celano, P.; Horowitz, C; Lau, H., and Koldovski, O.: Effect of Cortisone or Z-Triiodothyronine Administration to Preg nant Rats on the Activity of Fetal Intestinal Disaccharidases and Lysosomal Acid BGalactosidase 211

Pulkkinen, M.O. and Kero, P.: Effect of Proges terone on the Initiation of Respiration of the Newborn 218

Raye, J.R.; Dubin, J.W., and Blechner, J.N.: Fetal Growth Retardation following Maternal Morphine Administration: Nutritional or Drug Effect? 222

Hedner, T.; Lundborg, P., and Engel, J.: Effect of Hypoxia on Monoamine Synthesis in Brains of Developing Rats. II. Different Length of Exposure 229

No. 5-6

Solomon, S.; Iaina, A.; Eliahou, H., and Serban, I.: Postnatal Changes in Plasma and Renal Renin of the Rat 237

Klockars, M.; Reitamo, S., and Adinolfi, M.: Ontogeny of Human Lysozyme. Distribution in Fetal Tissues 243

Richardson, Ch. and Miller, A.J.: Variations of the Intraesophageal Pressure with Maturation in the Postnatal Piglet 250

Kreel, B.K. van and Dijk, J.P. van: Transport of Uric Acid and Hypoxanthine Across the Iso lated Guinea Pig Placenta 260 Mersmann, H.J.; Phinney, G.; Brown, L.J., and Steffen, D.G.: Ontogeny of Adenylate Cyclase and Phosphodiesterase Activities in Swine Tissues 266 Hahn, P.: Effect of Premature Weaning to Differ ent Diets on the Subsequent Response to a Dietary Change 275 Antonowicz, I.; Milunsky, A.; Lebenthal, E., and Shwachman, H.: Disaccharidase and Lysosomal Enzyme Activities in Amniotic Fluid, Intestinal Mucosa and Meconium. Correlation between Morphology and Disaccharidase Activities in Human Fetal Small Intestine .... 280 
Hudson, D.G.; Elphick, M.C., and Hull, D.: Dis tribution of Label in Maternal Plasma, Placen ta, Fetal Plasma and Tissues after Injection of '4C-Palmitate into the Circulation of 21- and 28-Day-Pregnant Rabbits 290

Demarne, Y.; Epo, N.; Lecourtier, M.J., and Flanzy, J.: Effects of Maternal Dodecanoic or Laurie Acid (C12:0) Feeding on Milk Fatty Acid Secretion and Lipogenesis in the Suck ling Rat 296

Cashore, W.J.; Horwich, A.; Laterra, J., and Oh, W.: Effect of Postnatal Age and Clinical Status of Newborn Infants on BilirubinBinding Capacity 304 Congote, L.F.; Bruno, F., and Solomon, S.: Effects of Testosterone and Estradiol on Ratios of Adult to Fetal Hemoglobin in Cell Cultures of Human Fetal Liver $\quad 310$ Amemiya, T.: Postnatal Maldevelopment of the Retina 319

Veyssière, G.; Berger, M.; Jean-Faucher, Ch.; Turckheim, M. de, and Jean, C: Effect of Luteinizing Hormone (LH) and LH-Releasing Hormone (LHRH) on Testosterone Produc tion In vivo, in Fetal Rabbit Testis in Late Gestation 327

Strbák, V. and Macho, L.: Increase of Serum Thyrotropin (TSH) of Suckling Rats after Thyroliberin (TRH) Injection to Lactating Mothers 331

Fevery, J.; De Wolf-Peeters, C; De Vos, R.; Desmet, V., and Heirwegh, K.P.M.: Perinatal Development of Bilirubin UDP-Glycosyltransferase Activities in Rat Liver 336 Vlontzou, K.; Hadjigeorgiou, E.; Constantinides, D.; Chrissikou, M., and Micolopoulos, D.: F2 $\alpha$ Prostaglandin Levels in Mothers and Infants of Different Gestational Periods 343 Letter to the Editor 346 Author Index 347 Subject Index 348 